\title{
Impact of Heat Stress Exposure During Meiotic Maturation on Oocyte, Surrounding Cumulus Cell, and Embryo RNA Populations
}

\author{
Rebecca R. PAYTON1), Louisa A. RISPOLI'), Arnold M. SAXTON1) and J. Lannett EDWARDS1) \\ 1)Department of Animal Science, The University of Tennessee Institute of Agriculture and AgResearch, Knoxville, TN \\ 37996-4574, USA
}

\begin{abstract}
To determine if reductions in developmental competence related to heat stress exposure were correlated with perturbations in certain RNA populations, poly(A) RNA, total RNA, RNA size distribution, and the abundance of transcripts (cyclin B1, GDF9, BMP15, poly(A) polymerase, HSP70, 18S \& 28S rRNA) were examined in oocytes matured at 38.5 or $41 \mathrm{C}$. Performing in vitro fertilization resulted in embryos for examining RNA. Relative to germinal vesiclestage oocytes, total amount of poly(A) RNA decreased similarly in oocytes matured at 38.5 or $41 \mathrm{C}$. Total RNA did not change during meiotic maturation or up through the 4 to 8-cell stage of embryonic development. Blastocyst-stage embryos had more total RNA; those originating from heat-stressed oocytes had more than those from nonheat-stressed oocytes. Oocytes and 4 to 8-cell embryos had similar RIN values and ratios for rRNA, 18S/fast region, and 18S/inter region. Values obtained for blastocyst-stage embryos were similar to those obtained for cumulus cell RNA, which did not change during maturation. Culture at $41 \mathrm{C}$ for the first $12 \mathrm{~h}$ of meiotic maturation had no impact on RNA size distribution or transcripts examined from oocytes, surrounding cumulus or resultant 4 to 8-cell embryos. Interestingly, however, RNA from blastocysts originating from heat-stressed oocytes had lower 18S/fast region and 18S/inter region ratios compared to other developmental stages and cumulus cells. Although biological significance of these RNA changes is unclear, differences at the molecular level in embryos from heat-stressed oocytes emphasize the importance of minimizing stress exposure during meiotic maturation, if the intent is to obtain developmentally-competent embryos.
\end{abstract}

Key words: Cumulus, Heat stress, Microcapillary electrophoresis, Oocyte, RNA

(J. Reprod. Dev. 57: 481-491, 2011)

A griculturally-important females exposed to environmental heat stress experience reduced fertility [1-4]. In cattle, this is largely due to hyperthermia [5-7] whereby rectal temperatures may reach or exceed $41 \mathrm{C}$ [5, 8-12]. Effects of environmental heat stress to reduce female fertility are pronounced during or near estrus [13-15]. This corresponds to the time period when the female is receptive to mating and the oocyte within the Graafian follicle resumes meiosis and progresses to metaphase II (MII; meiotic maturation) in preparation for fertilization. Hyperthermia during this time has been associated with reductions in early embryonic development [16] and increases in embryonic loss near the time of placental attachment [17].

The negative impact of hyperthermia during estrus may be attributable to indirect effects on the maternal environment [reviewed by 18] and/or due to direct effects on the cumulus-oocyte complex. Direct exposure of the cumulus-oocyte complex to $41 \mathrm{C}$ during meiotic maturation reduces early embryo development after fertilization by 30 to $65 \%$ [19-25] similar to consequences observed when environmental heat stress elevates rectal temperatures to $41 \mathrm{C}$ [16]. Marked changes occurring in the nucleus and ooplasm may explain why oocytes undergoing meiotic maturation are so susceptible to direct effects of heat stress. Unfortunately,

Received: October 28, 2010

Accepted: March 30, 2011

Published online in J-STAGE: April 9, 2011

(C)2011 by the Society for Reproduction and Development

Correspondence: JL Edwards (e-mail: jedwards@utk.edu) however, consequences go beyond the obvious of reducing blastocyst development after fertilization, and include yet unidentified heat-induced perturbations that continue to affect otherwise morphologically-normal embryos. For instance, Edwards et al. [26] showed that compact morula-stage embryos from heat-stressed oocytes are more susceptible to heat stress than embryos from nonheat-stressed oocytes. This finding is consistent with Rutigliano et al. [27] who reported that dairy cows exposed to heat stress during artificial insemination are more likely to lose their pregnancies than nonheat-stressed cows.

Heat-induced reductions in the developmental competence of bovine oocytes have been coincident with a 30 to $50 \%$ reduction in de novo synthesis of intracellular proteins [19]. In murine oocytes, reductions as high as $80 \%$ have been noted [28]. Although the underlying mechanisms remain unclear, results of Payton and Edwards [29] implicate heat-induced reductions in the level of polyadenylated (poly(A)) mRNA in bovine oocytes by $12 \mathrm{~h}$ of in vitro maturation. Even though differences were no longer detected at $24 \mathrm{~h}$, there is potential for heat stress to impact developmentallyimportant transcripts that may produce proteins required for proper embryo development [reviewed by 30], as upon resumption of meiosis and germinal vesicle breakdown the oocyte is transcriptionally quiescent [i.e., no longer capable of transcribing RNA; 31-33]. This transcriptional inactivity, or reliance upon maternal RNA stores for protein synthesis, persists through the third cleavage division in the bovine [8 to 16-cell stage; 34 ].

To determine if reductions in developmental competence of the 
oocyte after heat stress exposure during meiotic maturation are attributable to heat-induced perturbations in certain RNA populations, poly(A) RNA, total RNA, RNA size distribution, and the abundance of specific transcripts (i.e., growth and differentiation factor 9 (GDF9), bone morphogenetic protein 15 (BMP15), cyclin B1 (CCNB1), poly(A) polymerase (PAP), heat shock protein 70 (HSP70), 18S \& 28S rRNA) were examined. Choice of individual transcripts was based on importance in the oocyte, during maturation, or heat shock response [35-39, reviewed by 40]. Performing in vitro fertilization on subsets of oocytes allowed measurement of RNA populations in resultant embryos.

\section{Materials and Methods}

\section{Oocyte collection and selection criteria}

Bovine ovaries were purchased from a commercial abattoir (Brown Packing, Gaffney, SC, USA) originating predominantly from Angus, Holstein, Hereford, and Charlois cows. Oocytes were collected as previously described [24]. Only cumulus-oocyte complexes having multiple layers of tightly compacted cumulus and dark, homogenous ooplasm were selected for in vitro maturation (IVM). An experimental unit was a group (pool) of cumulusoocyte complexes cultured together within one well of a 4-well Nunclon culture dish (Fisher Scientific, Pittsburgh, PA, USA).

\section{General methods for sample processing and RNA extraction}

In vitro maturation, fertilization (IVF), and culture of resultant embryos were performed as previously described [23, 25, 26]. Briefly, cumulus-oocyte complexes were matured in Medium-199 containing Earle's salts, $10 \%$ fetal bovine serum, $50.0 \mu \mathrm{g} / \mathrm{ml}$ gentamicin, $5.0 \mu \mathrm{g} / \mathrm{ml} \mathrm{FSH}, 0.2 \mathrm{mM}$ Na pyruvate, and $2 \mathrm{mM} \mathrm{L}-$ glutamine) in a 5.5\% $\mathrm{CO}_{2}$ humidified environment. After $\sim 24 \mathrm{~h}$ of in vitro maturation (hIVM), IVF was performed with Percoll-prepared frozen-thawed semen (500,000 motile sperm/ml) generously provided by Ultimate Genetics (Wheelock, TX, USA) and Harrogate Genetics International (Harrogate, TN, USA). Putative zygotes were denuded of associated cumulus at 18 to $20 \mathrm{~h}$ post-IVF and cultured at $38.5 \mathrm{C}$ in a humidified environment of $5.5 \% \mathrm{CO}_{2}$, $7.0 \% \mathrm{O}_{2}$, and $87.5 \% \mathrm{~N}_{2}$ in potassium simplex optimized medium as per Schrock et al. [25]. Ability to undergo cleavage and blastocyst development was assessed on days 3 and 8 post-IVF, respectively. Blastocysts were assigned stage and quality scores as per Schrock et al. [25] according to guidelines set by the International Embryo Transfer Society [41].

For sample processing at the germinal vesicle (GV)-stage, oocytes soon after follicle removal were denuded of surrounding cumulus by vortexing [4.5 min in HEPES-PVA (HEPES-TL [42] supplemented with $0.3 \%$ polyvinyl alcohol (Sigma-Aldrich, St. Louis, MO, USA), $0.20 \mathrm{mM}$ sodium pyruvate (Sigma-Aldrich), and 0.5X penicillin/streptomycin (Millipore, Billerica, MA, USA)]. Oocytes at subsequent stages of IVM were also denuded by vortexing, but in $0.3 \%$ hyaluronidase (Sigma-Aldrich). The number of oocytes recovered and visibly lysed after denudement was recorded. Each oocyte was manipulated individually under a stereomicroscope to ensure complete removal of cumulus cells before transferring the group to a microcentrifuge tube in $3.5 \mu$ l HEPES-
PVA. Samples were lysed and extracted according to manufacturer's specifications for either Absolutely RNA Microprep kit (Stratagene, La Jolla, CA, USA) or PicoPure RNA Isolation kit (MDS Analytical Technologies, Sunnyvale, CA, USA), as indicated in the following sections describing experimental details. Lysates were stored at $-80 \mathrm{C}$ until RNA extraction.

Experiment 1: Abundance of the total amount of poly $(A) R N A$ in $G V$-stage or control and heat-stressed oocytes at 12, 16, 20, and 24 hIVM

Previous efforts had shown that the total amount of poly(A) mRNA decreased throughout meiotic maturation [29]. While heat stress exposure reduced levels observed at 12 hIVM, heat-induced differences in levels of poly(A) mRNA were not apparent at 24 hIVM. To determine when during meiotic maturation poly(A) RNA levels in heat-stressed oocytes return to control levels, cumulus-oocyte complexes were randomly assigned to a total of 9 treatments involving culture at 38.5 or $41.0 \mathrm{C}$ as per Fig. 1 . Prior to placement in maturation medium (i.e., 0 hIVM), a group of GVstage cumulus-oocyte complexes (Fig. 1, treatment 1) was denuded; cumulus-free $\mathrm{GV}$-stage oocytes were frozen at $-80 \mathrm{C}$ as pools of 60 in RNA lysis buffer (Stratagene). Control groups were placed in culture at $38.5 \mathrm{C}$ for 12 (Fig. 1, treatment 2), 16 (treatment 4), 20 (treatment 6), or 24 hIVM (treatment 8). Remaining cumulus-oocyte complexes were heat-stressed at $41 \mathrm{C}$ for the first $12 \mathrm{hIVM}$ and denuded (Fig. 1, treatment 3) or placed at 38.5 C until 16 (treatment 5), 20 (treatment 7), or 24 hIVM (treatment 9). Pools of cumulus-free oocytes ( $n=60 /$ pool) were frozen at -80 C in RNA lysis buffer. Total RNA, isolated using Absolutely RNA Microprep kit (Stratagene), was eluted in $30 \mu \mathrm{l}$. Total amount of poly(A) RNA was quantified using the Poly(A) mRNA Detection System (Promega, Madison, WI, USA) as per manufacturer's instructions using a six-point standard curve ranging from 0 to $200 \mathrm{pg} / \mu \mathrm{l}$ (interassay CV of 7.8\%).

On five different occasions, subsets of control and heat-stressed oocytes underwent IVF and were allowed to develop to the blastocyst stage to document the extent to which heat stress reduced developmental potential. Cleavage and blastocyst development were assessed at approximately $73 \mathrm{~h}$ post-IVF (hpi) and $192 \mathrm{hpi}$, respectively. This experiment was replicated on 13 different occasions ( $n=60$ oocytes/pool; 780 total per treatment) between January and middle of June using a total of 7,020 oocytes.

Experiment 2: RNA size distribution and abundance of certain transcripts in control and heat-stressed oocytes, their

surrounding cumulus cells, and resultant embryos

To determine if reductions in developmental competence are attributable to heat-induced perturbations in certain RNA populations, total RNA, RNA size distribution, and the abundance of specific transcripts (i.e., CCNB1, GDF9, BMP15, PAP, HSP70, $18 \mathrm{~S} \& 28 \mathrm{~S}$ rRNA) were examined in control and heat-stressed oocytes. Performing IVF on subsets tested the extent to which perturbations in various RNA populations affected resultant embryos.

Immediately after removal from ovarian follicles but before placement in maturation medium (i.e., 0 hIVM when oocytes were at GV-stage), or after IVM at 38.5 or $41.0 \mathrm{C}$ for 12 or $24 \mathrm{~h}$, subsets 


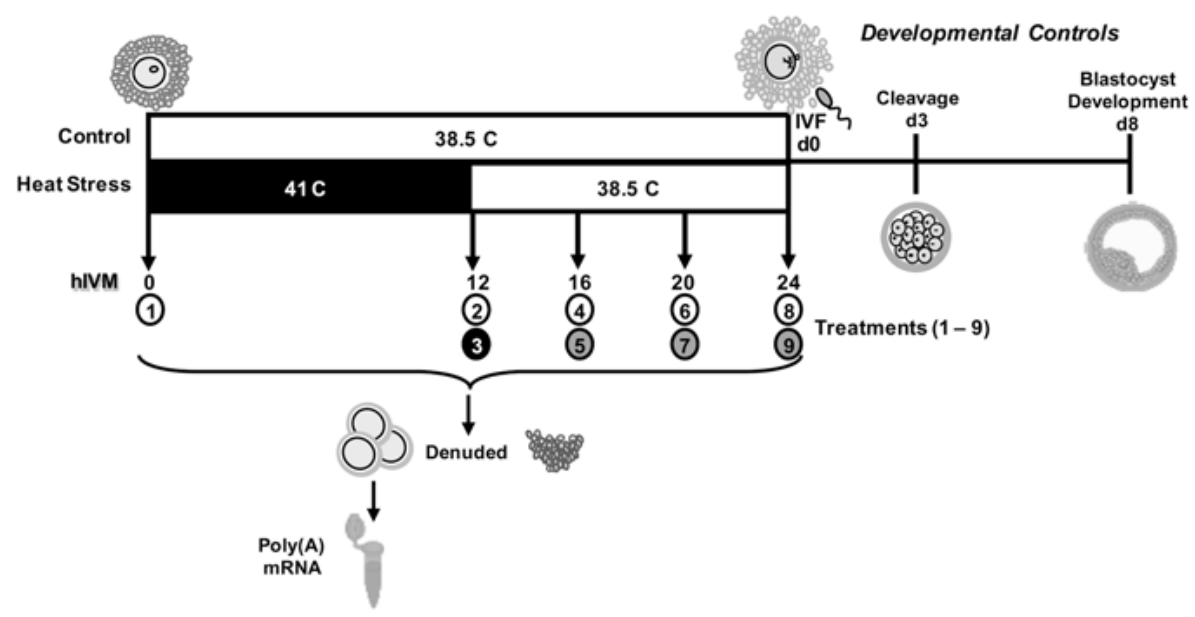

Fig. 1. Schematic of design for experiment 1. Cumulus-oocyte complexes were collected and randomly allotted to one of 9 treatments. Soon after removal from ovarian follicles, but before placement in in vitro maturation medium (i.e., 0 hIVM), oocytes (treatment 1 ) were denuded of surrounding cumulus and frozen in lysis buffer at $-80 \mathrm{C}$. Additional cumulus-oocyte complexes were cultured at $38.5 \mathrm{C}$ (indicated by white circles) for 12 (treatment 2), 16 (treatment 4), 20 (treatment 6), or 24 hIVM (treatment 8). Additional groups of oocytes were matured at $41.0 \mathrm{C}$ for the first 12 hIVM and denuded immediately (treatment 3; indicated by black circle) or cultured at $38.5 \mathrm{C}$ thereafter (indicated by gray circles) for a total of 16 (treatment 5), 20 (treatment 7), or $24 \mathrm{~h}$ (treatment 9). All cultured oocytes were denuded of cumulus at indicated time and stored in lysis buffer at $-80 \mathrm{C}$ until RNA extraction and analysis of poly(A) RNA. For 5 of the 13 replicates, a subset of cumulus oocyte complexes underwent in vitro fertilization (IVF) at 24 hIVM (designated as day 0 of embryo development); cleavage and blastocyst development were assessed on days 3 and 8 , respectively.

of oocytes were denuded, lysed in groups of 50 in $25 \mu \mathrm{l} \mathrm{RNA}$ extraction buffer (MDS Analytical) before storage at $-80 \mathrm{C}$ (Fig. 2, treatments 1 through 5). Cumulus cells from each group of oocytes were kept separate according to treatment origin, washed in HEPES-PVA, and pelleted for lysis in $200 \mu \mathrm{l}$ of RNA extraction buffer as per Fig. 2. Additional subsets of cumulus-oocyte complexes underwent IVF at 24 hIVM. At approximately $40.5 \mathrm{hpi}$, a subset of 4 and 8-cell embryos from control and heat-stressed oocytes ( $n=32$ to $117 /$ pool/replicate, mean=65.6) were removed from culture and lysed in $25 \mu$ l of RNA extraction buffer (Fig. 2, treatments 6 and 7). Ability of remaining embryos to undergo cleavage and blastocyst development was assessed at approximately 72 and 192 hpi, respectively. Blastocyst-stage embryos from control and heat-stressed oocytes (Fig. 2, treatments 8 and 9) were lysed in $25 \mu$ l of RNA extraction buffer ( $n=6$ to 35/pool/replicate, mean=14.4).

RNA was extracted using PicoPure kit as per manufacturer instructions and was DNase-treated on the column using TURBO DNase [4 (oocytes and embryos) or 16 units (cumulus), Applied Biosystems/Ambion; Austin, TX, USA] before elution. DNA-free RNA was eluted in an 11 or $20 \mu$ l volume, for oocytes/embryos and cumulus, respectively. Total RNA was quantified using Quant-iT RiboGreen RNA Reagent and kit (Invitrogen, Carlsbad, CA, USA) by analyzing $1 \mu$ l of eluted RNA (diluted 200×) in triplicate using a TBS-380 fluorometer (Turner BioSystems, Sunnyvale, CA, USA). Amount of total RNA per oocyte was calculated from simple linear regression of a standard curve ( 1 to $400 \mathrm{ng} / \mathrm{ml}$; interassay $\mathrm{CV}=$ $9.1 \%$ and $2.5 \%$ for 2000 - and 200 -fold dilution assays, respectively).

Microcapillary-electrophoretic separation and detection via laser-induced fluorescence using RNA 6000 Pico Lab Chips allowed for assessing size distribution of RNA [43] in oocytes, surrounding cumulus and resultant embryos as previously described by Payton et al. [44]. For each sample ( $1 \mu$ l of eluted RNA), the Bioanalyzer software generated a rRNA ratio (area under 28S peak divided by area under $18 \mathrm{~S}$ peak) and an RNA integrity number (RIN) which is an algorithm-based value taking into account all the regions of the electropherogram [43]. This value was derived to provide an unbiased metric of RNA integrity using all RNA sizes present within a sample. In addition, relative amounts of RNA sizes in the fast, 18S, inter, and 28S regions were estimated with the smear analysis for examining the proportion of 18S rRNA to smaller RNA sizes (i.e., those between 200 to 1500 nt; 18S/fast region ratio). This was done to estimate the abundance of smaller RNA sizes in a given sample relative to $18 \mathrm{~S}$ rRNA. Since $28 \mathrm{~S}$ rRNA is typically degraded before $18 \mathrm{~S}$ and is generally coincident with increased abundance of RNA sizes in the inter region [45, 46], an 18S/inter region ratio was also calculated.

Quantitative PCR analysis (qPCR) was utilized to assess the relative abundance of developmentally-important transcripts (Table 1). Primers were designed using Primer Express (Applied Biosystems, Foster City, CA, USA) or FastPCR (version 4.0.27; Institute of Biotechnology; University of Helsinki, Finland) from bovine sequences in GenBank. Before reverse transcription, oocyte and embryo RNA samples were spiked with 12 pg of green fluorescent protein (GFP) RNA per oocyte or embryo as an exogenous control for normalization of transcript abundance [47, 48]; cumulus samples were spiked with 500 pg per 100 ng total RNA. Green fluorescent protein construct with T7 promoter was linearized with EcoR1 (Fisher), in vitro transcribed (4 h at $37 \mathrm{C}$ ) using the MEGAscript kit (Ambion), and purified (MEGAclear kit; Ambion). Reverse transcription was performed with $500 \mathrm{ng}$ random hexam- 


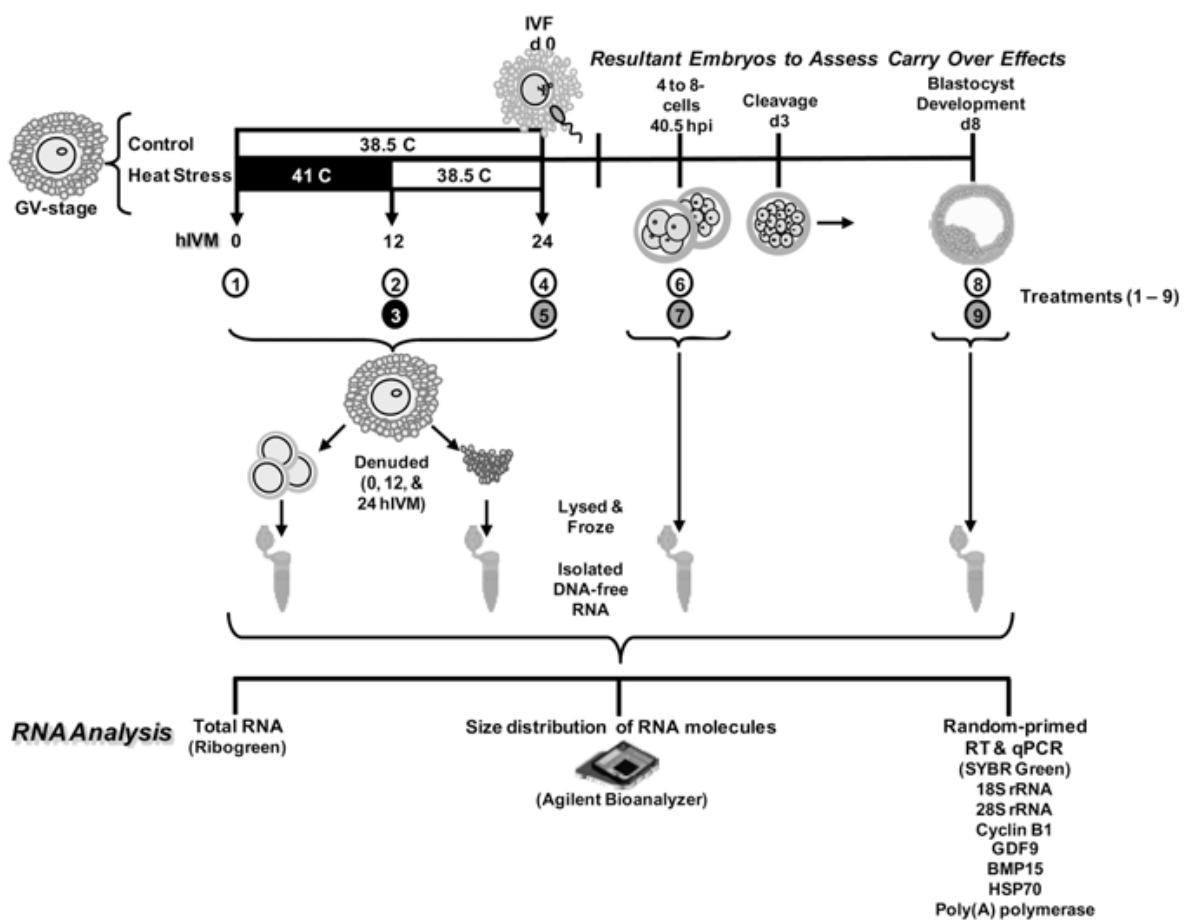

Fig. 2. Schematic of design for experiment 2. Cumulus-oocyte complexes were randomly allotted to culture at 38.5 for 0 (soon after removal from ovarian follicles but before placement in in vitro maturation medium), 12 or $24 \mathrm{hIVM}$ (indicated by white circles). Others were matured at $41.0 \mathrm{C}$ for $12 \mathrm{~h}$ and removed for analysis (indicated by black circle) or cultured for another $12 \mathrm{~h}$ at $38.5 \mathrm{C}$ (indicated by gray circles). At 0 and $24 \mathrm{hIVM}$, cumulus-free oocytes and their surrounding cumulus were lysed separately in extraction buffer and stored at -80 C until RNA extraction and analysis of total RNA, RNA integrity, and individual transcripts. Other remaining subsets of cumulus-oocyte complexes were subjected to in vitro fertilization (IVF; designated as day 0 of embryo development). Presumptive zygotes were denuded $18-20 \mathrm{~h}$ post insemination (hpi). A subset of 4 to 8-cell embryos was collected at $40.5 \mathrm{hpi}$ and processed for RNA analysis. Cleavage and blastocyst rates were assessed on remaining embryos on days 3 and 8, respectively. Blastocysts were processed for RNA analysis as indicated.

Table 1. Sequences of primers used for qPCR amplification of genes of interest

\begin{tabular}{llllcc}
\hline Gene & $\begin{array}{l}\text { GenBank } \\
\text { accession number }\end{array}$ & \multicolumn{1}{c}{ Forward primer $\left(5^{\prime} \rightarrow 3^{\prime}\right)$} & Reverse primer $\left(5^{\prime} \rightarrow 3^{\prime}\right)$ & $\begin{array}{c}\text { Product } \\
\text { size }(\mathrm{bp})\end{array}$ & $\begin{array}{c}\text { Final primer } \\
\text { concentration }(\mathrm{nM})\end{array}$ \\
\hline 18S $r$ RNA & AY779625 & AAGACGGACCAGAGCGAAAG & GGTCGGAACTACGACGGTATCT & 100 & 500 \\
28S $r$ RNA & AY639443.1 & TCTGGTGGAGGTCGTAGCGGT & TGCGTTTGCGAGAGCGCCAGCT & 139 & 500 \\
BMP15 & NM_001031752 & TGGAACATGTTGGGCAAAAG & AACTCACGAACCTCACTACCTCTTG & 100 & 500 \\
CCNB1 & L26548 & TCAGATTACTGCAGGAGACCATGT & ACTCCAACCAGCTGCAGCAT & 100 & 750 \\
GDF9 & NM_174681 & TTGCCTGGCTCTGTTTCCT & CAAGTCTCAGCCTCAGATTCCA & 100 & 750 \\
HSP70 & NM_203322 & ACGTCGTTGATCCTGTGGGCCGT & ACCTTGCCGTGCTGGAACACC & 147 & 750 \\
PAP & X63436 & AGCAGCCTCGACTTGTCTATGG & GAGAGCTGCCAGAACTGTTCAA & 100 & 250 \\
GFP & --- & CAACTTCAAGACCCGCCACA & TCTGGTAAAAGGACAGGGCCA & 102 & 750 \\
\hline
\end{tabular}

a Primers specific for bovine HSP70-1 (HSPA1A) and HSP70-2 (HSPA1B) located in tandem on chromosome 23 [84].

ers (Promega), 200 units MMLV-RT (Promega), 500 nM dNTP mix (Fisher Scientific), and 25 units Superase-in (Ambion) in 1X MMLV buffer to a final volume of $25 \mu \mathrm{l}$. Reverse transcription reactions (37 C for $1 \mathrm{~h}, 94 \mathrm{C}$ for $10 \mathrm{~min}$ ) were cooled to $4 \mathrm{C}$ before storage at $-20 \mathrm{C}$. A subset of RNA from each sample was reverse transcribed in the absence of enzyme and tested with each primer set to assess genomic contamination (RT-minus).

Efficiency for each primer set was between 90 and 110\% (where efficiency $=10^{(-1 / \text { slope })}-1$; slope of $-\log$ concentration of standard curve versus threshold cycle). To ensure specificity, PCR products were sequenced. Relative quantification was performed using Power SYBR Green PCR Master Mix (Applied Biosystems) in a 25 $\mu \mathrm{l}$ volume. The equivalent of 0.1 oocytes or embryos [similar to that reported by $49,50-53$ ] or 100 pg cumulus total RNA were analyzed in either duplicate or triplicate in a 7300 ABI Real-Time PCR System (Applied Biosystems) for 35 cycles at either $60 \mathrm{C}$ or $63 \mathrm{C}$ (28S and HSP70) for $30 \mathrm{sec}$ and $72 \mathrm{C}$ for $30 \mathrm{sec}$ followed by a dissociation curve. The calibrator sample was GV-stage oocyte or 
cumulus from GV-stage oocytes within each replicate. Normalized and calibrated data were analyzed using the $\Delta \Delta \mathrm{Ct}$ method (calculated with RQ Study Application of 7300 System SDS software as per manufacturer's specifications; Applied Biosystems).

This experiment was replicated on 23 different occasions between the months of October to December and January to May. Heat-induced blastocyst reductions $\geq 20 \%$ were observed for seven replicates, the data from which are presented [a total of 4,267 oocytes utilized to obtain oocyte pools of $\sim 50$ per each of 5 treatments after denuding (total of 2,090 oocytes), 340 and 3164 to 8cells per treatment (total of 6564 to 8-cells), and 122 and 79 blastocysts per treatment (total of 201 blastocysts)].

\section{Statistical analyses}

For each experiment, all results are presented as least squares means (LSM) \pm standard error of the mean (SEM) unless otherwise noted. Data obtained in the first experiment were analyzed as a randomized block design (RBD) using PROC GLIMMIX of SAS (SAS 9.1, SAS Institute, Cary, NC, USA) with main effect of treatment and random effect of replicate for normally-distributed data. A priori contrasts were performed to examine changes in poly(A) RNA over maturation. In addition, contrasts were performed to assess the effect of heat stress exposure on poly(A) at each time point, and the interaction of maturation time and temperature (factorial treatment design). Replicates with corresponding development data were analyzed separately to assess effects of poly(A) RNA levels during oocyte maturation on subsequent ability to develop into blastocyst stage embryos.

For the second experiment, embryo developmental data were analyzed as a RBD with factorial treatment design with main effects of hIVM (12 or 24 hIVM) and temperature (38.5 or $41.0 \mathrm{C}$ ) and random effect of replicate using PROC GLIMMIX with a binomial distribution. Stage and quality scores for blastocysts were analyzed similarly but with a normal distribution. Oocyte and embryo RNA data were analyzed as a randomized incomplete block (4 to 8-cell embryos not present in every replicate) with factorial treatment arrangement, random effect of replicate, and covariate for amount of RNA per qPCR reaction (since samples were loaded on a per oocyte or embryo basis). Cumulus RNA data were analyzed as a RBD with main effect of treatment and random effect of replicate using PROC GLIMMIX with a normal distribution. Experimental endpoints included total RNA, rRNA ratio, $\mathrm{RIN}, 18 \mathrm{~S} /$ fast region ratio, 18S/inter region ratio, and relative abundance of individual transcripts. Possible changes occurring during meiotic maturation were assessed by examining oocytes at GV-stage and those matured at $38.5 \mathrm{C}$ for 12 and $24 \mathrm{hIVM}$.

To determine if heat stress exposure during meiotic maturation altered the relative abundance of certain transcripts across development (i.e., GV-stage oocytes through blastocyst-stage embryos after fertilization), qPCR data for experimental replicates exhibiting heat-induced reductions in blastocyst development $\geq 20 \%$ were analyzed using multisource nonlinear mixed model regression (PROC NLMIXED; SAS). Quadratic (18S and 28S) or exponential decay (BMP15, CCNB1, GDF9, HSP70, and PAP) equations were used to fit transcript abundance curves for control and heat stress treatments.

\section{Results}

Experiment 1: Abundance of the total amount of poly $(A) R N A$ in $G V$-stage or control and heat-stressed oocytes at 12, 16, 20, and $24 \mathrm{hIVM}$

Recovery (97.2 to $98.6 \%$; SEM=0.7\%; $\mathrm{P}=0.79$ ) and lysis (1.7 to $3.1 \%$; SEM=0.5\%; $\mathrm{P}=0.73$ ) of oocytes after cumulus denudement by vortexing were similar regardless of hIVM or IVM temperature examined. However, amount of poly(A) RNA per oocyte differed depending upon duration of maturation $(\mathrm{P}<0.0001)$. Specifically, poly(A) RNA was highest in GV-stage oocytes and was markedly lower in oocytes after 12 hIVM ( $<<0.0001$; Fig. 3A). Poly(A) RNA levels per oocyte continued to decline up to 24 hIVM (Fig. 3A). There was no impact of heat stress exposure during the first 12 hIVM to affect poly(A) RNA levels at any of the time points examined ( $\mathrm{P}>0.25$; Fig. 3A).

To provide a more precise test of the hypothesis (i.e., heatinduced reductions in certain RNA populations during meiotic maturation may explain why a subset of oocytes fail to develop to the

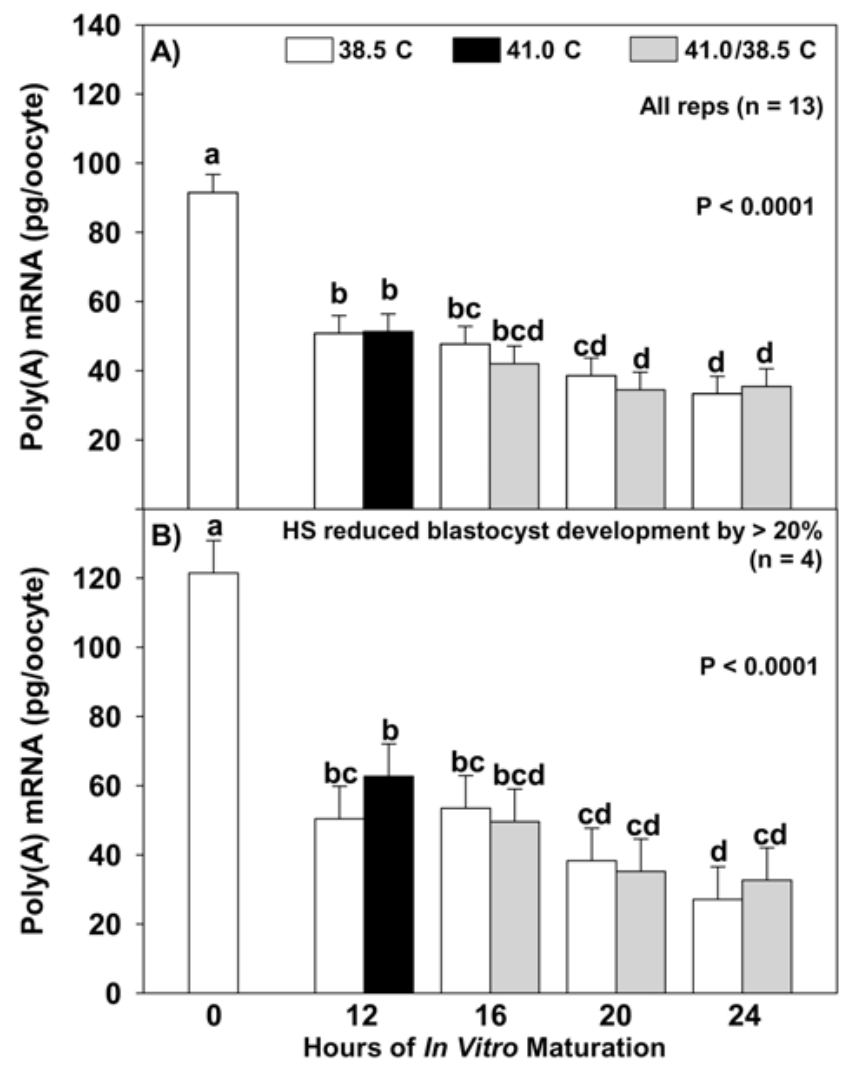

Fig. 3. Poly(A) RNA within oocytes matured at 38.5 or $41.0 \mathrm{C}$ for up to 24 hIVM. White bars indicate culture at $38.5 \mathrm{C}$ for $0,12,16,20$, or 24 hIVM. Black bar indicates heat stress for $12 \mathrm{~h}$. Gray bar indicates heat-stress for $12 \mathrm{~h}$ and culture at $38.5 \mathrm{C}$ thereafter. Data from all 13 replicates are provided in panel A. Data from the four replicates having heat-induced reductions in blastocyst development of at least $20 \%$ are provided in panel B. Least squares means \pm standard error of the mean are shown with treatment differences. Bars with different letters within a panel differ $(\mathrm{P}<0.0001)$. 
Table 2. Embryo development of control and heat-stressed oocytes after direct heat stress exposure reduced blastocyst development $\geq 20 \%$ (n=7 experimental replicates)

\begin{tabular}{lcccccc}
\hline \multicolumn{9}{c}{$\sim 72 \mathrm{hpi}^{\epsilon}$} & $\sim 192 \mathrm{hpi}^{\epsilon}$ \\
\hline IVM temperature & PZ $^{\ddagger}$ cultured & \% Cleaved (n) & \% 8 to 16-cell* (n) & \% Blastocysts/PZ (n) & Blastocyst stage & Blastocyst quality \\
\hline 38.5 C & 410 & $80.46 \pm 2.25(\mathrm{n}=329)$ & $81.99 \pm 2.59(\mathrm{n}=270)$ & $29.76 \pm 2.26^{\mathrm{a}}(\mathrm{n}=122)$ & $6.20 \pm 1.32$ & $1.13 \pm 0.09$ \\
41.0 C & 413 & $80.00 \pm 2.28(\mathrm{n}=329)$ & $79.01 \pm 2.82(\mathrm{n}=261)$ & $19.13 \pm 1.94^{\mathrm{b}}(\mathrm{n}=79)$ & $6.22 \pm 1.32$ & $1.30 \pm 0.09$ \\
& P-value & 0.87 & 0.38 & 0.004 & 0.92 & 0.2 \\
\hline
\end{tabular}

${ }^{\epsilon}$ hpi = hours post-IVF; ${ }^{\ddagger} \mathrm{PZ}=$ putative zygotes; * Proportion of cleaved embryos; ab Means within a column differ.

Table 3. Characteristics of total RNA from developmentally-competent oocytes having heat-induced reductions in blastocyst development of $\geq 20 \%$ ( $\mathrm{n}=7$ replicates)

\begin{tabular}{|c|c|c|c|c|c|c|c|c|}
\hline Cell type & Stage & $\begin{array}{l}\text { IVM temp }^{\dagger} \\
\text { (C) }\end{array}$ & $\begin{array}{c}\text { Treatment } \\
\text { ID }^{\ddagger}\end{array}$ & $\begin{array}{c}\text { Total } \\
\text { RNA** }\end{array}$ & $\begin{array}{c}\text { rRNA } \\
\text { ratio }\end{array}$ & RIN & $\begin{array}{c}18 \mathrm{~S} / \text { fast } \\
\text { region ratio }\end{array}$ & $\begin{array}{l}18 \mathrm{~S} / \text { inter } \\
\text { region ratio }\end{array}$ \\
\hline \multirow[t]{5}{*}{ Oocyte } & GV-stage & - & 1 & $1.82^{\mathrm{c}}$ & $0.87^{\mathrm{bc}}$ & 5.37 & $0.31^{\mathrm{a}}$ & $0.69^{\mathrm{b}}$ \\
\hline & 12 hIVM & 38.5 & 2 & $2.18^{\mathrm{bc}}$ & $0.65^{c}$ & 5.16 & $0.28^{\mathrm{a}}$ & $0.66^{\mathrm{b}}$ \\
\hline & & 41.0 & 3 & $2.10^{\mathrm{bc}}$ & $0.80^{\mathrm{bc}}$ & 5.18 & $0.28^{\mathrm{a}}$ & $0.64^{\mathrm{b}}$ \\
\hline & 24 hIVM & 38.5 & 4 & $2.41^{\mathrm{bc}}$ & $0.75^{\mathrm{bc}}$ & 5.08 & $0.29^{\mathrm{a}}$ & $0.65^{\mathrm{b}}$ \\
\hline & & 41.0 & 5 & $2.28^{\mathrm{bc}}$ & $0.84^{\mathrm{bc}}$ & 5.08 & $0.23^{\mathrm{a}}$ & $0.63^{b}$ \\
\hline \multirow[t]{6}{*}{ Embryo } & 4 to 8-cell & 38.5 & 6 & $2.64^{\mathrm{bc}}$ & $0.93^{\mathrm{b}}$ & 4.80 & $0.28^{\mathrm{a}}$ & $0.52^{\mathrm{bc}}$ \\
\hline & & 41.0 & 7 & $3.26^{\mathrm{bc}}$ & $0.80^{\mathrm{bc}}$ & 4.22 & $0.22^{\mathrm{ab}}$ & $0.51^{\mathrm{bc}}$ \\
\hline & Blastocyst & 38.5 & 8 & $3.80^{\mathrm{b}}$ & $1.78^{\mathrm{a}}$ & 6.06 & $0.22^{\mathrm{a}}$ & $0.85^{\mathrm{a}}$ \\
\hline & & 41 & 9 & $6.43^{\mathrm{a}}$ & $1.69^{\mathrm{a}}$ & 5.11 & $0.10^{\mathrm{b}}$ & $0.42^{\mathrm{c}}$ \\
\hline & & $S E M^{*}$ & & 0.81 & 0.10 & 0.46 & 0.04 & 0.06 \\
\hline & & P-value & & 0.0001 & $<0.0001$ & 0.46 & 0.02 & 0.002 \\
\hline \multirow[t]{7}{*}{ Cumulus } & GV-stage & - & $1 \mathrm{c}$ & 17.17 & 1.62 & 8.13 & 0.91 & 1.19 \\
\hline & 12 hIVM & 38.5 & 2c & 16.67 & 1.74 & 8.54 & 0.98 & 1.75 \\
\hline & & 41.0 & $3 c$ & 22.79 & 1.79 & 8.11 & 0.95 & 1.47 \\
\hline & 24 hIVM & 38.5 & $4 c$ & 20.40 & 1.74 & 8.31 & 1.00 & 1.74 \\
\hline & & 41.0 & $5 c$ & 28.24 & 1.60 & 8.51 & 1.29 & 1.68 \\
\hline & & $S E M^{*}$ & & 6.13 & 0.11 & 0.36 & 0.18 & 0.24 \\
\hline & & P-value & & 0.85 & 0.60 & 0.35 & 0.20 & 0.24 \\
\hline
\end{tabular}

${ }^{\dagger}$ IVM temperature; ${ }^{\ddagger}$ Treatment number from Fig. 2. ${ }^{* *}$ Total RNA is expressed as ng per oocyte or embryo. For cumulus, total RNA is expressed as ng of cumulus RNA per cumulus-oocyte complex denuded. "c" designates cumulus from oocytes within each treatment. * Pooled standard error of the mean (SEM); abc Different superscripts within a column indicate significant differences $(\mathrm{P}<0.05)$ for oocytes \& embryos.

blastocyst stage after fertilization), only those experimental replicates where heat stress exposure reduced blastocyst rates by $20 \%$ or more compared to controls were included in the analysis ( $\mathrm{n}=4$ replicates; 30.6 vs. 20.4\% blastocyst development for control and heatstressed oocytes, respectively; SEM=4.2\%; $\mathrm{P}=0.01$ ). Similar to previous results, poly(A) RNA was highest in GV-stage oocytes and decreased as maturation progressed (Fig. 3B). Even when the effect of heat stress was to reduce development by $\geq 20 \%$, there was no impact of $41 \mathrm{C}$ exposure during the first $12 \mathrm{hIVM}$ to alter poly(A) RNA per oocyte (Fig. 3B).

\section{Experiment 2: RNA size distribution and abundance of certain} transcripts in control and heat-stressed oocytes, their surrounding cumulus cells, and resultant embryos

Effects of heat stress exposure during meiotic maturation to reduce blastocyst development after IVF ranged from 0 to $55.3 \%$. To provide a more precise test of hypothesis, only those experi- mental replicates whereby heat stress reduced blastocyst rates by $\geq 20 \%$ are reported herein $(n=7)$. Developmental data for these experimental replicates are presented in Table 2. Notably, the proportion undergoing cleavage and progressing to the 8 to 16 -cell stage after IVF was similar for control and heat-stressed oocytes. However, heat stress exposure resulted in a $35.7 \%$ reduction in blastocyst development.

Analysis of oocytes not undergoing IVF showed that total RNA per oocyte did not change during meiotic maturation, nor was it impacted by exposure to $41 \mathrm{C}$ during the first 12 hIVM (Table 3). Total RNA in 4 to 8-cell embryos was similar to amounts observed in oocytes, whereas blastocyst-stage embryos had significantly more total RNA than all other stages examined. Interestingly, blastocysts from heat-stressed oocytes had higher amounts of total RNA than those from nonheat-stressed oocytes (Table 3). Total RNA in surrounding cumulus cells did not change during meiotic maturation and was not impacted by heat stress exposure (Table 3). 


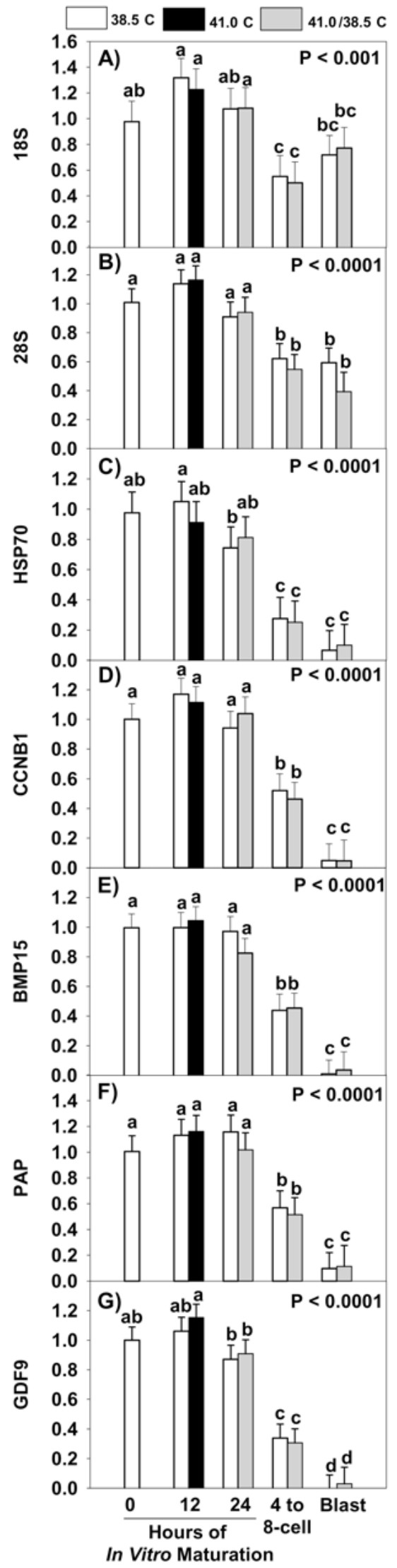

Analysis of RNA size distributions revealed similar RIN values and ratios for rRNA, 18S/fast region, and 18S/inter region for oocytes during meiotic maturation (Table 3). Four to 8-cell embryos had values comparable to those observed for oocytes, whereas values for blastocyst-stage embryos were most similar to those obtained for cumulus cell RNA which did not change during meiotic maturation (Table 3). When imposed during the first $12 \mathrm{~h}$ of meiotic maturation, $41 \mathrm{C}$ exposure had no impact on any of the RNA size distribution values reported herein for oocytes, surrounding cumulus or resultant 4 to 8 -cell embryos (Table 3 ). Interestingly however, RNA from blastocyst-stage embryos originating from heat-stressed oocytes had lower 18S/fast region and $18 S$ /inter region ratios compared to other developmental stages examined and cumulus cells (Table 3). Using multiple regression, it was determined that blastocyst development was not explained by total RNA $\left(\mathrm{R}^{2}=0.13 ; \mathrm{P}=0.20\right), 18 \mathrm{~S} /$ fast $\left(\mathrm{R}^{2}=0.01 ; \mathrm{P}=0.73\right)$ or $18 \mathrm{~S} /$ inter region $\left(\mathrm{R}^{2}=0.07 ; \mathrm{P}=0.42\right)$ ratios independently or collectively $\left(\mathrm{R}^{2}=0.28 ; \mathrm{P}=0.48\right)$. Additional analysis indicated that the total amount of RNA extracted per sample was directly proportional to the number of blastocysts in the lysate $(\mathrm{P}=0.1)$ and that the number of blastocysts per lysate did not affect total RNA per blastocyst $\left(\mathrm{R}^{2}=0.14 ; \mathrm{P}=0.18\right)$.

Overall, the relative abundance of $18 \mathrm{~S}$ rRNA, $28 \mathrm{~S}$ rRNA, HSP70, CCNB1, BMP15, PAP, and GDF9 transcripts was similar in GV-stage and matured oocytes but lower in 4 to 8-cell and blastocyst-stage embryos (Fig. 4). Exposure to $41 \mathrm{C}$ for the first 12 hIVM did not alter the abundance of any transcripts examined in oocytes or in resultant embryos after fertilization (Fig. 4). A few transcripts including CCNB1, BMP15, PAP, and GDF9 had a lower relative abundance in blastocysts than 4 to 8-cell embryos (Figs. 4D, E, F, G). Regression analysis was performed to better clarify changes in transcript abundance from onset of meiotic maturation to blastocyst-stage embryos. Doing so revealed quadratic behavior of $18 \mathrm{~S}$ and 28S rRNA and exponential decay of HSP70, CCNB1, BMP15, PAP, and GDF9 transcripts (data not shown). Exposure of maturing oocytes to $41 \mathrm{C}$ during the first $12 \mathrm{hIVM}$ did not alter the pattern of transcript abundance for the stages of development examined (data not shown).

In surrounding cumulus cells, relative quantity of $18 \mathrm{~S}$ rRNA did not change as oocyte maturation progressed (Fig. 5A). However, 28S rRNA was lower in cumulus from GV-stage oocytes compared to those matured for 12 hIVM (Fig. 5B). Quantity of CCNB1 transcripts decreased in step-wise fashion as maturation progressed

Fig. 4. Relative abundance of transcripts per oocyte or embryo for replicates $(\mathrm{n}=7)$ where culture at $41.0 \mathrm{C}$ during the first $12 \mathrm{~h}$ of maturation reduced blastocyst development $(\geq 20 \%)$ after fertilization. Data are least squares means \pm standard error of the mean with treatment differences indicated by letter designation at significance level indicated for each panel. White bars indicate culture at $38.5 \mathrm{C}$ for 0,12 , or 24 hIVM or embryos derived from oocytes cultured at 38.5 C. Black bar indicates heat stress for $12 \mathrm{~h}$. Gray bar indicates heat-stress for first 12 hIVM and culture at $38.5 \mathrm{C}$ thereafter. A) 18S rRNA, B) $28 \mathrm{~S}$ rRNA, C) heat shock protein 70 (HSP70), D) cyclin B1 (CCNB1), E) bone morphogenetic protein 15 (BMP15), F) poly(A) polymerase (PAP), and G) growth and differentiation factor 9 (GDF9). 

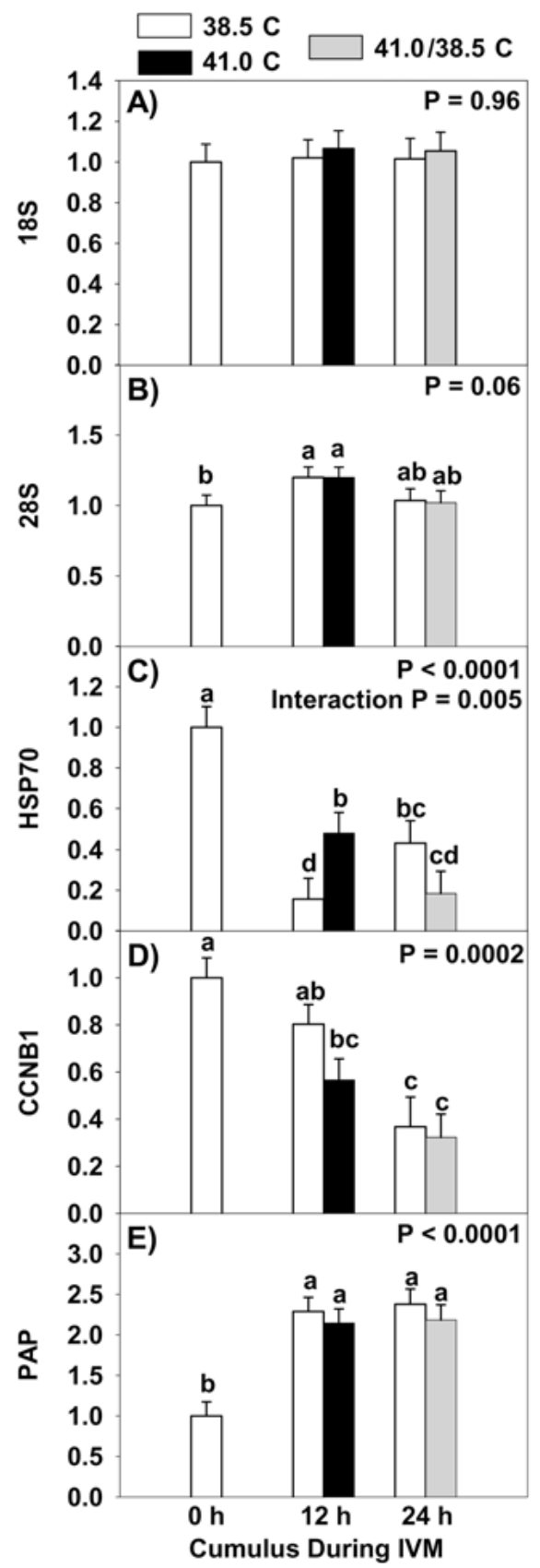

Fig. 5. Relative abundance of transcripts for surrounding cumulus cells of oocytes in replicates where culture at $41.0 \mathrm{C}$ during the first 12 h of maturation reduced blastocyst development ( $\geq 20 \%)$ after fertilization. A) 18S rRNA, B) $28 \mathrm{~S}$ rRNA, C) heat shock protein 70 (HSP70; significant interaction between culture temperature and time of maturation), D), cyclin B1 (CCNB1), and E) poly(A) polymerase (PAP). White bars indicate culture at $38.5 \mathrm{C}$ for 0 , 12, or 24 hIVM. Black bar indicates heat stress for first 12 hIVM. Gray bar indicates heat-stress for first 12 hIVM and culture at $38.5 \mathrm{C}$ for the remaining $12 \mathrm{hIVM}$. Least squares means \pm standard error of the mean are shown with treatment differences indicated by letter designation at significance level indicated for each panel.
(Fig. 5D). Transcripts for PAP in cumulus cells were significantly lower at the onset of maturation than at 12 or 24 hIVM (Fig. 5E). There was no effect of heat stress during the first 12 hIVM on 18S rRNA, 28S rRNA, CCNB1, or PAP transcript abundance. In contrast, there was a significant interaction between maturation time and temperature for HSP70 transcripts $(\mathrm{P}=0.005)$. Specifically, relative abundance of HSP70 was higher in cumulus from heatstressed oocytes at 12 hIVM compared to controls but difference was no longer detected at 24 hIVM (Fig. 5C). No transcripts for BMP15 or GDF9 were detected in cumulus cell RNA.

\section{Discussion}

A major aim of these studies was to relate changes in developmental competence after heat stress exposure during meiotic maturation to changes, or lack thereof, in certain oocyte and cumulus cell RNA populations (sizes $>200$ nucleotides (nt)). RNA populations were also examined after IVF to evaluate the extent to which heat-induced perturbations occurring during meiotic maturation were inherited by resultant embryos. To this end, it was shown that heat stress exposure during the first $12 \mathrm{~h}$ of meiotic maturation had minimal impact on the abundance of RNA populations and individual transcripts examined in oocytes, their surrounding cumulus cells, or in resultant 4 to 8-cell embryos. In contrast, blastocyst-stage embryos from heat-stressed oocytes had more total RNA which exhibited lower 18S/fast region and 18S/inter region ratios when compared to that of blastocysts from nonheat-stressed oocytes, suggesting a higher abundance of RNA sizes less than $3200 \mathrm{nt}$.

These results are significant as they document the extent to which heat-induced perturbations occurring at the molecular level during meiotic maturation are inherited by later stage embryos after fertilization. This is not likely without consequence as previous efforts of Edwards et al. [26] showed that later stage embryos from heat-stressed oocytes are not as developmentally-competent as those from nonheat-stressed oocytes. While the underlying mechanisms remain unclear, increased amount of total RNA in embryos from heat-stressed oocytes has been coincident with heat-induced perturbations in metabolism inherited by the embryo. To this end, recent efforts have shown that heat stress exposure during meiotic maturation increases metabolic activity (i.e., increases intracellular ATP content) which may persist in resultant embryos after fertilization up through the blastocyst stage (Payton et al., unpublished). Interestingly, Nilsson et al. [54] reported that higher total RNA content in cold-starved Helicobacter pylori was coincident with increased ATP content.

Different mRNA sizes in mammals range from approximately 300 to $6500 \mathrm{nt}$, with an average length of $1400 \mathrm{nt}$ [55]. In our study, heat-induced increases in total RNA content in blastocyststage embryos from heat-stressed oocytes were related to increases in RNA sizes $\leq 3200 \mathrm{nt}$. Whether RNA sizes in this range represent some level of degradation or increased abundance of certain mRNAs warrants further study. In support of the latter, Mortensen et al. [56] showed that equine blastocysts originating from oocytes experiencing heat stress at the end of IVM had higher HSP70 levels relative to $18 \mathrm{~S}$ rRNA than blastocysts from nonheat-stressed 
oocytes.

Assessments regarding nuclear stage of oocytes or enumeration of embryonic nuclei were not performed before placement into RNA lysis buffer as fixation with formalin-derivatives had been shown to not only to reduce total RNA yield and alter RNA integrity $[57,58]$ but also to chemically modify RNA such that it can no longer be utilized in qPCR studies [59]. Rather, blastocysts were assigned a numeric stage and quality score. In our study, there was no difference in the average stage or quality of blastocysts from heat-stressed or control oocytes, in agreement with previous findings $[25,26]$. Within a given culture system, blastocyst stage scores are highly correlated with total cell number [e.g., expanded blastocysts assigned a stage score of 7 will have more total cells on average than normal blastocysts assigned a stage score of $6 ; 60]$. Thus, obtaining similar stage and quality scores is consistent with numerous other studies reporting equivalent cell numbers in embryos from control and heat-stressed oocytes [22, 23, 61-66]. This reduces concerns related to marring results interpretation due to possible differences in morphology or total cell number. Moreover, a posteriori analysis using multisource regression revealed that results were not influenced by embryo number per RNA lysate.

Although without a discernible effect of heat stress, results described herein provide additional insight regarding certain features of oocyte RNA and how they compare to early embryo and cumulus cell RNA. To this end, total RNA did not change during meiotic maturation which is consistent with previous findings for bovine oocytes [44, 67]. The amount of RNA obtained for GVstage and matured oocytes was in agreement with others [ 2 ng/ oocyte; 67,68$]$. Finding similar amounts of total RNA in oocytes and 4 to 8-cell embryos but higher levels in blastocyst-stage embryos was also consistent with a recent report by Gilbert et al. [69]. Considering that the cytoplasm and its components are almost entirely from the oocyte [70] and major embryonic genome activation has not yet occurred [71], it is not surprising that certain features of RNA from 4 to 8-cell embryos are similar to oocyte RNA. The blastocyst-stage embryo being largely comprised of trophectoderm cells (i.e., the first epithelium) provides some explanation as to why this RNA is similar to that obtained from the somatic-like cumulus cells.

Depending on the species and stage, poly(A) RNA comprises approximately 10 to $20 \%$ of total RNA in oocytes [67, 72] and declines by 30 to $50 \%$ during meiotic maturation [this study, 67 , 72-74]. In the present study, heat stress exposure had no impact on the total amount of poly(A) RNA. Disparity with an earlier observation [29], while difficult to explain, may be related to inherent differences among individual batches of oocytes related to genotype [75], individual donors [76], physiological status of donor cows (disease [77] or nutrition [78]), subtle differences in oocyte collection, ovary transport, and oocyte evaluation, and/or other yet unidentified factors. Whatever the reason, absence of heat-induced reductions in poly(A) RNA, even when blastocyst development was reduced by $>30 \%$, minimizes concerns related to reduced developmental potential of oocytes after exposure to a physiologically-relevant elevated temperature. This is consistent with Lequarre et al. [67] reporting similar amounts of total poly(A) RNA in cow versus calf oocytes previously shown to differ in developmental competence [79]. Rather, developmental differences are more often related to changes occurring at the transcript level. For example, Patel et al. [47] showed a positive association of follistatin mRNA abundance with oocyte competence.

Relative abundance of transcripts examined in this study remained unchanged during meiotic maturation which is consistent with results reported by others [GDF9 and BMP15: 51, PAP: 52, CCNB1: 80, 81]. Poly(A) polymerase (PAP) transcripts were examined to provide insight into heat-induced reductions in poly(A) RNA content previously noted by Payton and Edwards [29]. While abundance of PAP was not altered in oocytes, this transcript increased in the intimately associated [reviewed by 82] and transcriptionally-active [83] cumulus cells by 12 hIVM. Interestingly, the only noted consequence of exposure of cumulusoocyte complexes to elevated temperature was increased cumulus cell HSP70 mRNA, effectively serving as a reminder that some of the negative heat stress effects on the oocyte may be mediated through the surrounding cumulus cells.

In summary, results described herein document the extent to which heat-induced perturbations occurring at the molecular level during meiotic maturation affect later stage embryos after fertilization. Previous efforts of Edwards et al. [26] demonstrating that later stage embryos from heat-stressed oocytes are not as developmentally-competent as those from nonheat-stressed oocytes suggests that heat-induced alterations in RNA may not be without consequence. Demonstrated differences occurring at the molecular level in embryos from heat-stressed oocytes emphasizes the importance of minimizing stress exposure during meiotic maturation. This is of particular importance if the intent is to obtain developmentally-competent embryos.

\section{Acknowledgments}

This research was supported in part by National Research Initiative Competitive Grant No. 2004-35203-14772 from the USDA Cooperative State Research, Education, and Extension Service, USDA Hatch Funds, the state of Tennessee through the Tennessee Agricultural Experiment Station, and the Department of Animal Science. Appreciation is extended to Dr N Stewart and L GoodAbercrombie for GFP plasmid.

\section{References}

1. Badinga L, Collier RJ, Thatcher WW, Wilcox CJ. Effects of climatic and management factors on conception rate of dairy cattle in subtropical environment. J Dairy Sci 1985, 68: 78-85.

2. Dunlap SE, Vincent CK. Influence of postbreeding thermal stress on conception rate in beef cattle. J Anim Sci 1971; 32: 1216-1218.

3. Dutt RH. Critical period for early embryo mortality in ewes exposed to high ambient temperature. J Anim Sci 1963; 22: 713-719.

4. Tompkins EC, Heidenreich CJ, Stob M. Effect of post-breeding thermal stress on embryonic mortality in swine. J Anim Sci 1967; 26: 377-380.

5. Monty DE, Jr, Wolff LK. Summer heat stress and reduced fertility in Holstein- Friesian cows in Arizona. Am J Vet Res 1974; 35: 1495-1500.

6. Biggers BG, Geisert RD, Wetteman RP, Buchanan DS. Effect of heat stress on early embryonic development in the beef cow. J Anim Sci 1987; 64: 1512-1518.

7. Ulberg LC, Burfening PJ. Embryo death resulting from adverse environment on spermatozoa or ova. J Anim Sci 1967; 26: 571-577.

8. Ealy AD, Drost M, Hansen PJ. Developmental changes in embryonic resistance to adverse effects of maternal heat stress in cows. J Dairy Sci 1993; 76: 2899-2905. 
9. Gaalaas RF. Effect of atmospheric temperature on body temperature and respiration rate of Jersey cattle. J Dairy Sci 1945; 28: 555-563.

10. Elvinger F, Natzke RP, Hansen PJ. Interactions of heat stress and bovine somatotropin affecting physiology and immunology of lactating cows. J Dairy Sci 1992; 75: 449462.

11. Roman-Ponce H, Thatcher WW, Wilcox CJ. Hormonal interrelationships and physiological-responses of lactating dairy cows to a shade management system in a subtropical environment. Theriogenology 1981; 16: 139-154.

12. Seath DM, Miller GD. The relative importance of high temperature and high humidity as factors influencing respiration rate, body temperature, and pulse rate of dairy cows. J Dairy Sci 1946; 29: 465-472.

13. Cavestany D, el-Wishy AB, Foote RH. Effect of season and high environmental temperature on fertility of Holstein cattle. J Dairy Sci 1985; 68: 1471-1478.

14. Gwazdauskas FC, Thatcher WW, Wilcox CJ. Physiological, environmental, and hormonal factors at insemination which may affect conception. J Dairy Sci 1973; 56: 873877

15. Stott GH, Williams RJ. Causes of low breeding efficiency in dairy cattle associated with seasonal high temperatures. J Dairy Sci 1962; 45: 1369-1375.

16. Putney DJ, Drost M, Thatcher WW. Influence of summer heat stress on pregnancy rates of lactating dairy cattle following embryo transfer or artificial insemination. Theriogenology 1989; 31: 765-778.

17. Cartmill JA, El-Zarkouny SZ, Hensley BA, Rozell TG, Smith JF, Stevenson JS. An alternative AI breeding protocol for dairy cows exposed to elevated ambient temperatures before or after calving or both. J Dairy Sci 2001; 84: 799-806.

18. Rensis FD, Scaramuzzi RJ. Heat stress and seasonal effects on reproduction in the dairy cow-a review. Theriogenology 2003; 60: 1139-1151.

19. Edwards JL, Hansen PJ. Elevated temperature increases heat shock protein 70 synthesis in bovine two-cell embryos and compromises function of maturing oocytes. Biol Reprod 1996; 55: 340-346.

20. Edwards JL, Hansen PJ. Differential responses of bovine oocytes and preimplantation embryos to heat shock. Mol Reprod Dev 1997; 46: 138-145.

21. Roth Z, Hansen PJ. Involvement of apoptosis in disruption of developmental competence of bovine oocytes by heat shock during maturation. Biol Reprod 2004; 71: 18981906

22. Roth Z, Hansen PJ. Sphingosine 1-phosphate protects bovine oocytes from heat shock during maturation. Biol Reprod 2004; 71: 2072-2078.

23. Edwards JL, Saxton AM, Lawrence JL, Payton RR, Dunlap JR. Exposure to a physiologically relevant elevated temperature hastens in vitro maturation in bovine oocytes. J Dairy Sci 2005; 88: 4326-4333.

24. Lawrence JL, Payton RR, Godkin JD, Saxton AM, Schrick FN, Edwards JL. Retinol improves development of bovine oocytes compromised by heat stress during maturation. J Dairy Sci 2004; 87: 2449-2454.

25. Schrock GE, Saxton AM, Schrick FN, Edwards JL. Early in vitro fertilization improves development of bovine ova heat stressed during in vitro maturation. J Dairy Sci 2007; 90: 4297-4303.

26. Edwards JL, Bogart AN, Rispoli LA, Saxton AM, Schrick FN. Developmental competence of bovine embryos from heat-stressed ova. J Dairy Sci 2009; 92: 563-570.

27. Rutigliano HM, Lima FS, Cerri RL, Greco LF, Vilela JM, Magalhaes V, Silvestre FT, Thatcher WW, Santos JE. Effects of method of presynchronization and source of selenium on uterine health and reproduction in dairy cows. J Dairy Sci 2008; 91: 33233336

28. Curci A, Bevilacqua A, Mangia F. Lack of heat-shock response in preovulatory mouse oocytes. Dev Biol 1987; 123: 154-160.

29. Payton RR, Edwards JL. Effects of heat stress on RNA pools within maturing bovine oocytes. Biol Reprod 2005; Special Issue: 135 (abstract W243).

30. Minami N, Suzuki T, Tsukamoto S. Zygotic gene activation and maternal factors in mammals. J Reprod Dev 2007; 53: 707-715.

31. Fair T, Hulshof SC, Hyttel P, Greve T, Boland M. Nucleus ultrastructure and transcriptional activity of bovine oocytes in preantral and early antral follicles. Mol Reprod Dev 1997; 46: 208-215.

32. Lodde V, Modina S, Maddox-Hyttel P, Franciosi F, Lauria A, Luciano AM. Oocyte morphology and transcriptional silencing in relation to chromatin remodeling during the final phases of bovine oocyte growth. Mol Reprod Dev 2008; 75: 915-924.

33. Rodman TC, Bachvarova R. RNA synthesis in preovulatory mouse oocytes. J Cell Biol 1976; 70: 251-257.

34. Barnes FL, First NL. Embryonic transcription in in vitro cultured bovine embryos. Mol Reprod Dev 1991; 29: 117-123.

35. Draetta G, Luca F, Westendorf J, Brizuela L, Ruderman J, Beach D. Cdc2 protein kinase is complexed with both cyclin A and B: evidence for proteolytic inactivation of MPF. Cell 1989; 56: 829-838.

36. Labbe JC, Capony JP, Caput D, Cavadore JC, Derancourt J, Kaghad M, Lelias JM, Picard A, Doree M. MPF from starfish oocytes at first meiotic metaphase is a het- erodimer containing one molecule of cdc2 and one molecule of cyclin B. Embo J 1989 8: 3053-3058.

37. Eppig JJ. Oocyte control of ovarian follicular development and function in mammals Reproduction 2001; 122: 829-838.

38. Hartl FU. Molecular chaperones in cellular protein folding. Nature 1996; 381: 571-579.

39. McNatty KP, Juengel JL, Reader KL, Lun S, Myllymaa S, Lawrence SB, Western A Meerasahib MF, Mottershead DG, Groome NP, Ritvos O, Laitinen MP. Bone morphogenetic protein 15 and growth differentiation factor 9 co-operate to regulate granulosa cell function in ruminants. Reproduction 2005; 129: 481-487.

40. Raabe T, Bollum FJ, Manley JL. Primary structure and expression of bovine poly(A) polymerase. Nature 1991; 353: 229-234.

41. Robertson I, Nelson RE. Certification and identification of the embryo, In: Stringfellow DA, Seidel SM (eds.), Manual of the International Embryo Transfer Society, Savoy, IL, 1998: 103-107.

42. Parrish JJ, Susko-Parrish J, Winer MA, First NL. Capacitation of bovine sperm by heparin. Biol Reprod 1988; 38: 1171-1180.

43. Schroeder A, Mueller O, Stocker S, Salowsky R, Leiber M, Gassmann M, Lightfoot S, Menzel W, Granzow M, Ragg T. The RIN: an RNA integrity number for assigning integrity values to RNA measurements. BMC Mol Biol 2006; 7: 3 .

44. Payton RR, Rispoli LA, Edwards JL. General features of certain RNA populations from gametes and cumulus cells. J Reprod Dev 2010; 56: 583-592.

45. Nadano D, Sato TA. Caspase-3-dependent and -independent degradation of $28 \mathrm{~S}$ ribosomal RNA may be involved in the inhibition of protein synthesis during apoptosis initiated by death receptor engagement. J Biol Chem 2000; 275: 13967-13973.

46. Venkov PV, Hadjiolov AA. Differential stability of 28 S and $18 \mathrm{~S}$ rat liver ribosomal ribonucleic acids. Biochem J 1969; 115: 91-94.

47. Patel OV, Bettegowda A, Ireland JJ, Coussens PM, Lonergan P, Smith GW. Functional genomics studies of oocyte competence: evidence that reduced transcript abundance for follistatin is associated with poor developmental competence of bovine oocytes. Reproduction 2007; 133: 95-106.

48. Tremblay K, Vigneault C, McGraw S, Sirard MA. Expression of cyclin B1 messenger RNA isoforms and initiation of cytoplasmic polyadenylation in the bovine oocyte. Biol Reprod 2005; 72: 1037-1044.

49. Bettegowda A, Patel OV, Ireland JJ, Smith GW. Quantitative analysis of messenger RNA abundance for ribosomal protein L-15, cyclophilin-A, phosphoglycerokinase, beta-glucuronidase, glyceraldehyde 3-phosphate dehydrogenase, beta-actin, and histone H2A during bovine oocyte maturation and early embryogenesis in vitro. Mol Reprod Dev 2006; 73: 267-278.

50. Donnison M, Pfeffer PL. Isolation of genes associated with developmentally competent bovine oocytes and quantitation of their levels during development. Biol Reprod 2004; 71: 1813-1821.

51. Lonergan P, Gutierrez-Adan A, Rizos D, Pintado B, de la Fuente J, Boland MP. Relative messenger RNA abundance in bovine oocytes collected in vitro or in vivo before and $20 \mathrm{hr}$ after the preovulatory luteinizing hormone surge. Mol Reprod Dev 2003; 66 : 297-305.

52. Racedo SE, Wrenzycki C, Herrmann D, Salamone D, Niemann H. Effects of follicle size and stages of maturation on mRNA expression in bovine in vitro matured oocytes. Mol Reprod Dev 2008; 75: 17-25.

53. Vigneault C, Gilbert I, Sirard MA, Robert C. Using the histone H2a transcript as an endogenous standard to study relative transcript abundance during bovine early development. Mol Reprod Dev 2007; 74: 703-715.

54. Nilsson HO, Blom J, Abu-Al-Soud W, Ljungh AA, Andersen LP, Wadstrom T. Effect of cold starvation, acid stress, and nutrients on metabolic activity of Helicobacter pylori. Appl Environ Microbiol 2002; 68: 11-19.

55. Sommer SS, Cohen JE. The size distributions of proteins, mRNA, and nuclear RNA. J Mol Evol 1980; 15: 37-57.

56. Mortensen CJ, Choi YH, Ing NH, Kraemer DC, Vogelsang MM, Hinrichs K. Heat shock protein 70 gene expression in equine blastocysts after exposure of oocytes to high temperatures in vitro or in vivo after exercise of donor mares. Theriogenology 2010; 74: 374-383.

57. Cox ML, Schray CL, Luster CN, Stewart ZS, Korytko PJ, Khan KNM, Paulauskis JD, Dunstan RW. Assessment of fixatives, fixation, and tissue processing on morphology and RNA integrity. Exp Mol Pathol 2006; 80: 183-191.

58. Goldsworthy SM, Stockton PS, Trempus CS, Foley JF, Maronpot RR. Effects of fixation on RNA extraction and amplification from laser capture microdissected tissue. Mol Carcinog 1999; 25: 86-91.

59. Masuda N, Ohnishi T, Kawamoto S, Monden M, Okubo K. Analysis of chemical modification of RNA from formalin-fixed samples and optimization of molecular biology applications for such samples. Nucleic Acids Res 1999; 27: 4436-4443.

60. Knijn HM, Gjorret JO, Vos PL, Hendriksen PJ, van der Weijden BC, Maddox-Hyttel P, Dieleman SJ. Consequences of in vivo development and subsequent culture on apoptosis, cell number, and blastocyst formation in bovine embryos. Biol Reprod 2003; 69 : 
1371-1378.

61. Soto P, Smith LC. BH4 peptide derived from Bcl-xL and Bax-inhibitor peptide suppresses apoptotic mitochondrial changes in heat stressed bovine oocytes. Mol Reprod Dev 2009; 76: 637-646.

62. Ju JC, Jiang S, Tseng JK, Parks JE, Yang X. Heat shock reduces developmental competence and alters spindle configuration of bovine oocytes. Theriogenology 2005; 64: $1677-1689$.

63. Tseng JK, Ju JC. Calcium release of heat-shocked porcine oocytes induced by thimerosal or inositol 1,4,5-trisphosphate (IP3). Anim Reprod Sci 2009; 111: 41-53.

64. Tseng JK, Liu HK, Lin TA, Yang CR, Yang X, Ju JC. Calcium release and development of heat-shocked porcine oocytes after nucleus-ooplasm reconstruction. Cloning Stem Cells 2009; 11: 557-563.

65. Tseng JK, Tang PC, Ju JC. In vitro thermal stress induces apoptosis and reduces development of porcine parthenotes. Theriogenology 2006; 66: 1073-1082.

66. Yuan Y, Hao ZD, Liu J, Wu Y, Yang L, Liu GS, Tian JH, Zhu SE, Zeng SM. Heat shock at the germinal vesicle breakdown stage induces apoptosis in surrounding cumulus cells and reduces maturation rates of porcine oocytes in vitro. Theriogenology 2008; 70: 168-178.

67. Lequarre AS, Traverso JM, Marchandise J, Donnay I. Poly(A) RNA is reduced by half during bovine oocyte maturation but increases when meiotic arrest is maintained with CDK inhibitors. Biol Reprod 2004; 71: 425-431.

68. Bilodeau-Goeseels S, Schultz GA. Changes in ribosomal ribonucleic acid content within in vitro-produced bovine embryos. Biol Reprod 1997; 56: 1323-1329.

69. Gilbert I, Scantland S, Sylvestre EL, Gravel C, Laflamme I, Sirard MA, Robert C. The dynamics of gene products fluctuation during bovine pre-hatching development. Mol Reprod Dev 2009; 76: 762-772.

70. Smith LC, Alcivar AA. Cytoplasmic inheritance and its effects on development and performance. J Reprod Fertil Suppl 1993; 48: 31-43.

71. Memili E, Dominko T, First NL. Onset of transcription in bovine oocytes and preimplantation embryos. Mol Reprod Dev 1998; 51: 36-41.

72. De Leon V, Johnson A, Bachvarova R. Half-lives and relative amounts of stored and polysomal ribosomes and poly(A) + RNA in mouse oocytes. Dev Biol 1983; 98: 400408

73. Biase FH, Fonseca Merighe GK, Santos Biase WK, Martelli L, Meirelles FV. Global poly(A) mRNA expression profile measured in individual bovine oocytes and cleav- age embryos. Zygote 2008; 16: 29-38.

74. Gomez E, Rodriguez A, Goyache F, Diez C, Jose Royo L, Moreira PN, Nestor Caamano J, Moran E, Gutierrez-Adan A. Retinoid-dependent mRNA expression and poly-(A) contents in bovine oocytes meiotically arrested and/or matured in vitro. Mol Reprod Dev 2004; 69: 101-108.

75. Rocha A, Randel RD, Broussard JR, Lim JM, Blair RM, Roussel JD, Godke RA Hansel W. High environmental temperature and humidity decrease oocyte quality in Bos taurus but not in Bos indicus cows. Theriogenology 1998; 49: 657-665.

76. Tamassia M, Heyman Y, Lavergne Y, Richard C, Gelin V, Renard JP, Chastant-Maillard S. Evidence of oocyte donor cow effect over oocyte production and embryo development in vitro. Reproduction 2003; 126: 629-637.

77. Fray MD, Mann GE, Clarke MC, Charleston B. Bovine viral diarrhoea virus: it effects on ovarian function in the cow. Vet Microbiol 2000; 77: 185-194.

78. Armstrong DG, Gong JG, Webb R. Interactions between nutrition and ovarian activity in cattle: physiological, cellular and molecular mechanisms. Reprod Suppl 2003; 61 403-414

79. Khatir $\mathbf{H}$, Lonergan $\mathbf{P}$, Touze $\mathbf{J} \mathbf{L}$, Mermillod $\mathbf{P}$. The characterization of bovine embryos obtained from prepubertal calf oocytes and their viability after non surgical embryo transfer. Theriogenology 1998; 50: 1201-1210.

80. Heikinheimo O, Lanzendorf SE, Baka SG, Gibbons WE. Cell cycle genes c-mos and cyclin-B1 are expressed in a specific pattern in human oocytes and preimplantation embryos. Hum Reprod 1995; 10: 699-707.

81. Pennetier S, Uzbekova S, Perreau C, Papillier P, Mermillod P, Dalbies-Tran R. Spatio-temporal expression of the germ cell marker genes MATER, ZAR1, GDF9, BMP15, and VASA in adult bovine tissues, oocytes, and preimplantation embryos. Biol Reprod 2004; 71: 1359-1366

82. Eppig JJ. Oocyte-somatic cell communication in the ovarian follicles of mammals. Sem Dev Biol 1994; 5: 51-59.

83. Tirone E, D'Alessandris C, Hascall VC, Siracusa G, Salustri A. Hyaluronan synthesi by mouse cumulus cells is regulated by interactions between follicle-stimulating hormone (or epidermal growth factor) and a soluble oocyte factor (or transforming growth factor beta1). J Biol Chem 1997; 272: 4787-4794

84. Gallagher DS, Jr, Grosz MD, Womack JE, Skow LC. Chromosomal localization of HSP70 genes in cattle. Mamm Genome 1993; 4: 388-390. 